\title{
LARGE MINERAL ACTIVITY: A SOCIAL, ECONOMIC AND ENVIRONMENTAL APPROACH THROUGH GEOTECHNOLOGIES
}

\author{
D. P. S. Carvalho ${ }^{1 *}$, C. G. Barreto ${ }^{1}$, J. Garnier ${ }^{1}$, R. E. Cicerelli ${ }^{1}$, D. Cambraia ${ }^{1}$, P. T. A. Martins ${ }^{2}$, E. B. Silva ${ }^{3}$ \\ ${ }^{1}$ Institute of Geosciences (IGD/UNB), University of Brasília, Brazil - (daniela.pereira.ufg, crisgbarreto, garnier.geol, \\ daciocambraia)@gmail.com, rejaneig@unb.br \\ ${ }^{2}$ Natural Resources of Cerrado (RENAC/UEG), Goiás State University, Brazil - patrick_thomaz@ yahoo.com.br \\ ${ }^{3}$ Image Processing and Geoprocessing Laboratory (LAPIG/UFG), Goiás Federal University, Brazil - elainesilvaufg@gmail.com
}

KEY WORDS: Mining, Environmental and socioeconomic impacts, Geoprocessing, Temporal analysis, Landscape, Remote sensing

\begin{abstract}
:
Mining is one of the most important economic activities in Goiás, and it is necessary for the municipalities. The abundance of some mineral substances in the state makes Goiás a desirable location for large extraction companies. This research paper outlines that landscape alteration is inevitable, as it is necessary to remove natural areas for the exploitation of minerals. Agricultural areas could be effected by this process. This paper is discussing a evolution of mining activity that was done with the corporation of Alto Horizonte between 1985 and 2015, observing intervals of a decade, and relating this change to the socio-economic data of the municipality. Remote sensing techniques were used in conjunction with Geographic Information System (GIS), two such techniques include: satellite, image classification and data from socioeconomic surveys. Which provided the basis for relating them to the information generated by the mappings. Through quantitative analysis and visual observations of the mappings of the enterprise and its surroundings, it was possible to notice the modification of the landscape. In addition, socioeconomic data could indicate the influence that mining has had on Alto Horizonte. Although the enterprise has a high industrial mineral production and raise the city's GDP, it is not invested in better wages for the population, ie, workers' income does not keep up with the minimum wage increase.
\end{abstract}

\section{INTRODUCTION}

Investments in the mining sector are made in regions where the natural resource is geologically inserted. Positive and negative impacts on the environment, society, and economy arise as a result of these investments. The area affected and the intensity of these impacts depends on the characteristics of each project, especially whether they are open-pit or underground mining (Yaylaci, Düzgün, 2016).

Mineral resources are an important economic development factor for Goiás, as this state stands out due to the occurrence of mineral deposits such as phosphate, limestone, asbestos, copper, nickel, vermiculite, gold, emerald, niobium and cobalt. This fact projects Goiás as the third state in Brazil to collect the Financial Compensation for the Exploration of Mineral Resources (CFEM), as shown in the 2010 Yearbook of the National Department of Mineral Production (DNPM) (DNPM, 2010). Of the eighteen largest reserves of mineral resources in the state, five are in the Northern Goiás Mesoregion, three in the Northwest Mesoregion, six in the Southern Mesoregion, three in the Eastern Mesoregion and one in the Central Goiano Mesoregion (DNPM, 2013; Cardoso Júnior, Lunas, 2016).

The mining activity involves a high capital value with high investments, but this venture modifies the socioeconomic and environmental conditions of the municipalities that it is based on, as well as the adjacent areas. From the analysis of transformations and environmental impacts by remote imaging technology, it is possible to verify changes in the use of land cover and thus be able to relate to socioeconomic data of the municipalities in which the companies are located (Barreto, 2001).

In the north of the state of Goiás, there is a greater concentration of large companies in the mineral segment due to the great availability and diversity of mineral substances, thus favoring the economic performance of the region. However, different socioeconomic conditions are noted in the cities, in addition, the activity in question significantly transforms the environment and, consequently, the landscape (Ellovitch, 2010).

Nevertheless, in the literature, there are few studies that relate the mineral activity of companies with the environmental and socioeconomic environment in Goiás. Usually, works of these themes aim to investigate the influence of mining companies in nearby cities, however, without relating the evolutionary dynamics of the city and the environment. Information on mineral production and the actual changes to the environment by the enterprises is very difficult to obtain, because of the negative impacts on the environment. The information could show the confidential data throughout their process and the influence of mineral commodities in the national economic market (Ellovitch, 2010).

Many authors do not yet conceptualize landscape beyond sight, beauty, harmonic or cultural, do not take an approach uniting the field and city areas in a globalized universe. However, nowadays it is already noticeable a larger amount of works that present the challenges of the landscape considering the anthropic actions related to it. Therefore, for Cavalcanti (2004), Corrêa (2008) and Britto et al., (2011) the concept of landscape has an interaction between society and nature which generates a relationship of arrangement in space that is demonstrated through characteristics of the region in which it is located, which constitute a dynamic, complex and physical system, formed by interacting elements and undergoing anthropic transformation. Thus, Coelho et al. (2014) observed that anthropic actions promote changes in land use and occupation and cause major impacts on landscapes, but their mitigation is possible through monitoring by using spatiotemporal data of these changes that occur in the landscape. Novo (1992)

\footnotetext{
* Corresponding author
} 
indicates a methodology using orbital information for this monitoring since the effects of land use and occupation of large areas can be better observed through the use of data from orbital sensor systems, which allow a set of information from the fast and meaningful mode.

Studies on the negative effect of the relationship between progressive landscape change by mining with nearby municipalities and the environment may help decision-makers to promote initiatives aimed at the well-being of the environment and the local population. Thus, the objective of this study is to obtain a temporal analysis of the physical and socio-economic aspects of the changes that the large mining causes, positively and negatively, in the area of Mining Maracá Indústria e Comércio S/A - MMIC, besides its surroundings, in the municipality in it is located - Alto Horizonte.

\section{MATERIALS AND METHODS}

\subsection{Area of study}

Subsidiary of the Canadian group Yamana Gold, Mineração Maracá Indústria e Comércio S/A - MMIC is located in the municipality of Alto Horizonte, northern Goiás state, Brazil (Figure 1).

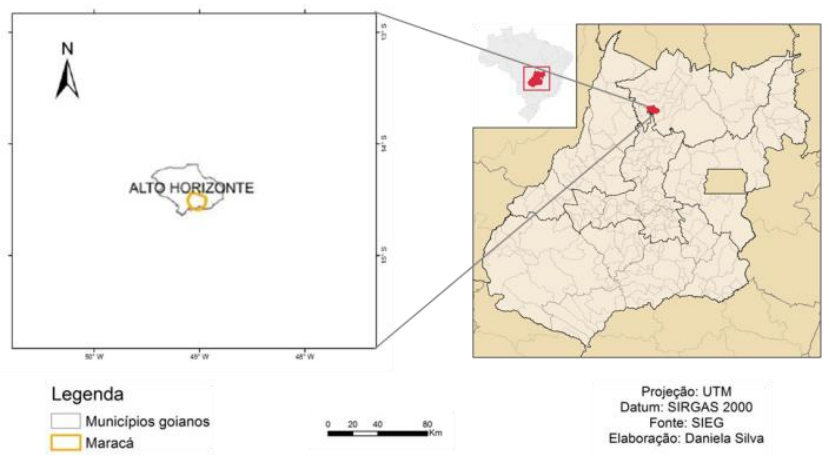

Figure 1. Location map of the municipality and mineral enterprise.

The Maracá mining company stated in 1973, from a geological research campaign of Mineração Serra do Leste Ltda, associated with Eluma S / A Indústria e Comércio (MMIC, 2013).

\subsection{Landsat 5 and 8 Image Processing}

For the temporal analysis of the conditions of land use and occupation in the study area, Landsat satellite images were used due to the good spatial resolution, the availability of long-term scenes and the free acquisition of them. The timeframe of this was 1985 to 2015 , at intervals of one decade, and it was necessary to use images from two Landsat series sensors: TM (Thematic Mapper) - 1985 to 2005 and OLI (Operational Land Imager) - 2015, both with a spatial resolution of thirty meters. The scenes of each year were chosen between the months of June to October to be, according to Sano et al. (2007), a period of lower cloud occurrence in the Cerrado biome. The mapping steps for land-use change and land cover are shown in Figure 2.

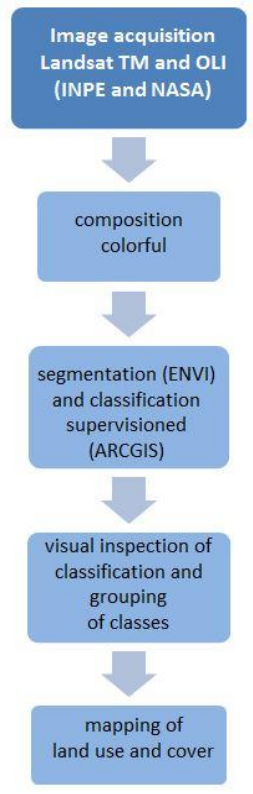

Figure 2. Flowchart of the methodological steps of land use and land cover mapping.

The images used are available and orthorectified (the process of geometrically correcting the images) through the portal from which the downloads were made (http://earthexplorer.usgs.gov/).

Through the images available on Google Earth, the area of the mineral enterprise was delimited. This delimitation, in generated vector structure, was transformed into a file in shapefile format (polygons). A $10 \mathrm{~km}$ buffer was adopted, comprising this distance as the mining company's area of influence in the municipality in question, according to Santos (2004).

Image classification is a process that consists of grouping pixels into classes pre-established or not by the user, based on their characteristics. Therefore, its goal is to recognize pixel classes in the image to identify ground cover types according to the target spectral response patterns (Jensen, 2005).

Thus, the Supervised Classification was performed and the Maximum Likelihood classification algorithm was used, as this method evaluates the variance and covariance of training samples in spectral response when an unknown pixel is classified, assuming that the distribution of the point cloud that forms the data sample is the normal distribution.

To perform the supervised classification of the images, the following textural classes were created: Agriculture, Urban Area, Mine Area, Body of Water, Pasture, Vegetation and Other. The "Others" class was created from the sum of items such as airport, gold panning, relief shadow, burnings, roads, and rocky outcrops, thus having less influence on the project area.

The image classification process used in this research is considered semi-automatic since it was performed through visual interpretation polygon to polygon (Figure 3) due to its features of greater consistency and efficiency after segmentation in ENVI 5.0 software (Sano et al., 2007). 


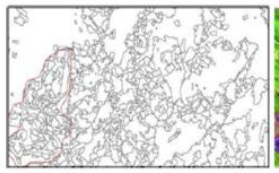

a) Polygons obtained after classification by segmentation.

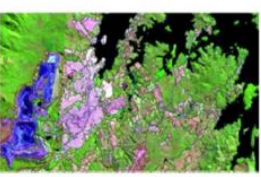

b) Polygons overlaid visual inspection step. the raw image and new

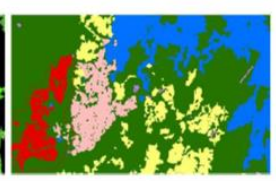

c) Inspection and new class creation process completed.
Figure 3. Visual inspection process performed after the segmentation classification process exemplified by a mining company.

The quality analysis process was performed from validation samples using the confusion matrix and the Kappa index. In order to define the minimum quantity of reference points for analysis, Jensen's indications (1986) were considered. The Kappa index measures the degree of digital classification agreement with field truth and has been calculated according to the equation below:

$$
k=\frac{n \sum_{i=n}^{c} x_{i i}-\sum_{i=n}^{c} x_{i}+x+i}{n^{2}-\sum_{i=n}^{c} x_{i}+x+i}
$$

Where: $\mathrm{K}$ = Kappa concordance coefficient;

$\mathrm{n}=$ Number of observations (sampling points);

xii $=$ Remarks in row $\mathrm{i}$ and column $\mathrm{i}$;

$\mathrm{xi}+=$ Total marginal row $\mathrm{i}$;

$\mathrm{x}+\mathrm{i}=$ Total marginal column $\mathrm{i}$.

To evaluate the Kappa index, Table 1 was adopted, adapted from Galparsoro and Fernández (2001).

\begin{tabular}{cc}
\hline Kappa's values & Concordance \\
\hline$<0,20$ & Poor \\
$0,21-0,40$ & Low \\
$0,41-0,60$ & Moderate \\
$0,61-0,80$ & High \\
$0,81-1,00$ & Very High \\
\hline
\end{tabular}

Source: Adapted from Galparsoro and Fernández (2001).

Table 1. Value to evaluate the degree of agreement from the Kappa index.

The validation of the products resulting from the classification of the images was obtained through visual interpretation and field visits in the study areas, ie "in loco". To aid in the interpretation of the targets, high-resolution images made available online by Google Earth were used. The consultation sought to reduce interpretation difficulties in distinguishing targets in these areas. The main obstacles stand out the confusion between the pasture and cerrado drainage classes.

\subsection{Socioeconomic Aspects}

Socioeconomic data on wage income, number of inhabitants, GDP per capita, minimum wage and economic sectors were obtained from IBGE (Brazilian Institute of Geography and Statistics), IMB (Mauro Borges Institute) and Atlas Brasil, which were based on to relate the information generated by the mapping with the economic and social aspects of the municipality. IMB (2015) provides data containing information on the value added by each of the sectors (agriculture, industry, and services), the value of GDP and the population of Alto Horizonte. However, these data are restricted from the years 1999 to 2013; the years 1999, 2005 and 2013 were used to perform the socioeconomic analyzes of the city.

\subsection{Results and discussion}

The research results were related between the geographic aspects in the mineral enterprise and in adjacent areas and the socioeconomic characteristics in the municipality where it is located. The geographical aspects were analyzed the areas of mining Maracá and surrounding areas, thus addressing their land use classes. In the socioeconomic aspect, the influence of the mineral sector on the economy of the municipality was analyzed. This influence was obtained by comparing the increase in the per capita income of the city with the minimum wage. In which the minimum wage in 2000 and 2010 were, respectively, $\mathrm{R} \$ 151,00$ and $\mathrm{R} \$ 510,00$.

\subsubsection{Mappings}

The availability of satellite images provided supervised classification. Which gave rise to the mapping of the 1985, 1995, 2005 and 2015 decades in which they demonstrate the evolution of land use and landscape alteration. Thus, it was possible to identify the land use classes of the mine area and its surroundings, and also to verify that the class that was most anthropically modified was that of vegetation since it was mainly transformed into the pasture. In addition, the mappings demonstrated the decade when the mining area expanded most due to the increase in mineral production, ie 2015.

The quantitative mapping data was organized and arranged in Table 1 according to the land use classes identified in the image classification and the decades generated, thus demonstrating the absolute values of the areas to be analyzed.

The results for the Kappa index were considered as high concordance according to Galparsoro and Fernández (2001), obtaining the value of $72 \%$ (0.72) of general accuracy of the maps for classification. The classification of the generated images is consistent with the data produced by the company (EIA - Environmental Impact Study and RIMA - Environmental Impact Report) on the explored area. Since between 1985 and 2005 little was explored on the surface. However, in the last decade, 2015, there was a significant increase (of $\sim 500 \%$ ) in the area explored (Table 1 and Figure 4).

Due to the growth in production of the industrial plant, in January 2009, the volume of tailings produced annually also increased, requiring the anticipation of the construction of tailings dam elevations. Technological development is advancing every day and there is a need for mineral industrial growth, which causes an increase in the volume of tailings disposed of in the environment. This situation is brought to light by Mirim (2019), because the population on Earth increases every day, it is inevitable that the demand for mineral commodities will not grow. So more steel, more copper, more metals for battery production, more cement, more aggregates for construction and more fertilizers are produced to meet human demand. As production increased, so did the demand for water for the process. To meet this demand a catchment was installed in the Bois River, and the water was pumped to the Baco Pari dam. The dam now has the function of water accumulation and tailings, a fact that can be observed as a body of water in the year 2015 mapping in Figure 4 (MMIC, 2013). 

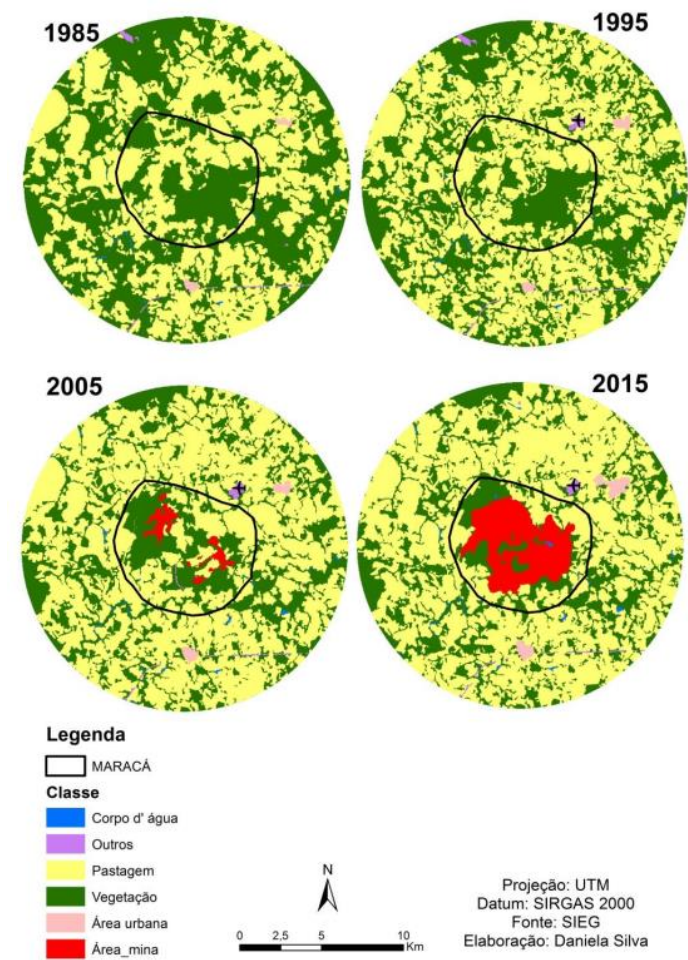

Figure 4. Spatio-temporal mappings performed in the images of the Maracá mining area in Alto Horizonte.

Given the expressive growth of the extraction area in the last decade, it is easily seen the company has increased its size over time. The development of the company's mineral processes skyrocket since 2003, the year in which MMIC took full control of the venture.

According to the analyzes carried out in the mappings generated here, in the study area (Figure 4), and information available in MMIC's environmental reports. Another indication of the previously referred to statement is the absence of production between 1985 and 1995. The same period in which vegetation reduced as a result of increased pasture activity in the municipality. With the occupation of the soil in the area of the mine, the areas destined for vegetation decreased year after year, starting in 2005 . It is possible to notice the transformation of the vegetation in the pasture because agriculture has always been a characteristic of the region (Table 2). However, as of 2005, pasture and vegetation have been reduced at the mine site due to the explosive increase in the area for the exploitation of mineral commodities.

\begin{tabular}{l|llll}
\hline Maracá & \multicolumn{4}{c}{$\begin{array}{l}\text { Area of textural and adjacent } \\
\text { classes }\left(\mathrm{km}^{2}\right)\end{array}$} \\
$\begin{array}{l}\text { Textural } \\
\text { classes }\end{array}$ & 1985 & 1995 & 2005 & 2015 \\
\hline Urban area & 0,92 & 1,16 & 1,38 & 2,51 \\
Area_mining & 0 & 0 & 3,86 & 23,06 \\
Water body & 0,53 & 0,52 & 0,93 & 0,95 \\
Others & 0,97 & 0,93 & 1,28 & 1,08 \\
Pasture & 158,08 & 181,15 & 204,14 & 197,80 \\
Vegetation & 151,30 & 128,09 & 100,26 & 86,47 \\
\hline
\end{tabular}

Table 2. Information classes and their respective adjacent areas $\left(\mathrm{km}^{2}\right)$ of the mining company Maracá from 1985 to 2015.
In the images, it is possible to verify the presence of another urban cluster just below the mining region. This is the municipality of Nova Iguaçu de Goiás, which is also influenced and economically benefited by MMIC.

The supervised image classification of semiautomatic Landsat 5 and 8 satellites (visually inspected polygon to polygon) proved satisfactory since, through combining the researchers' experience together with Google Earth verification, it was possible to differentiate the classes of use and coverage. The technique generated some limitations that made the interpretation of the data difficult, such as: not being able to imagine the bottom of the mine pits, confusion of some textural classes and that relatively small areas are not identifiable and underground mines cannot be measured.

\subsubsection{Socioeconomic Aspects}

In 1991, Alto Horizonte was just a village with few inhabitants. In 2000 , more than $64 \%$ of the population lived in the municipality. This process continued between 2000-2010, resulting in 2010 in more than $85 \%$ of the population installed in the urban area of Alto Horizonte (Atlas Brasil, 2013).

The municipality stands out at the state level for its GDP per capita, as shown in Table 3. Coherently, the proportion of below the poverty line in 2010 was below $7 \%$, while that of the extremely poor was $1.38 \%$. Therefore, we can see the influence of mineral activity on the growth of the economy in the municipality (Atlas Brasil, 2013).

\begin{tabular}{llllll}
\hline $\begin{array}{l}\text { Alto } \\
\text { Horizon } \\
\text {-te }\end{array}$ & Farming & Industry & $\begin{array}{l}\text { Servi- } \\
\text { ces }\end{array}$ & GDP & $\begin{array}{l}\text { Popula- } \\
\text { tion }\end{array}$ \\
\hline 1999 & 2.131 & 539 & 3.279 & 6.184 & 2.891 \\
2005 & 5.947 & 1.284 & 7.875 & 16.565 & 2.825 \\
2013 & 11.941 & 388.064 & $\begin{array}{l}141.65 \\
3\end{array}$ & 564.304 & 5.140 \\
\hline
\end{tabular}

Source: IBGE, Diretoria de Pesquisas, Coordenação de Contas Nacionais, 1999 a 2013.

Elaboration: Instituto Mauro Borges / Segplan-GO / Gerência de Contas Regionais e Indicadores - 2015.

Table 3. Value Added by Sector, Gross Domestic Product (GDP) at current prices and population, considering municipality - Alto Horizonte - 1999 to 2013 (R \$ thousand).

The average income per capita in Alto Horizonte has grown by about $200 \%$ over the last twenty years, from R\$213.55 in 1991 to $\mathrm{R} \$ 305.61$ in 2000 and $\mathrm{R} \$ 661.19$ in 2010 . These values are equivalent to an annual growth rate of $6.97 \%$ between 2000 and 2010.

Following the growing trend of other cities that have large mining companies, Alto Horizonte has developed in all branches of the economy. Between 2005 and 2013, highlighting factor is the increase in GDP, reflecting the start of ore extraction operations carried out in 2005. The installation of MMIC and the expansion of mineral production attracted many people who were looking for a job to the city. This doubled the population in less than five years. However, the population of Alto Horizonte is not considered high compared to other cities in Goiás that have mining economic base because their population has just over 5.000 inhabitants. The GDP represents significant value, representing the second-highest value per capita of the state of Goiás. 
When comparing average salary of Alto Horizonte with the minimum wage, it was noted that in 2000 , each inhabitant had an income of 2.02 minimum wages. In 2010 this value decreased to 1.29. Confirming that, despite the municipality has the second-largest GDP of the state of Goiás and high mineral production, these values are not invested in better wages for the general population, in other words, the income of workers does not follow the increase in the minimum wage.

There are different ways to assume the performance of the mineral enterprise in the community, ranging from a null or limited role to a leading role. Pasco-Font et al. (2003) describes three different types of corporate behavior:

- Welfare: when dealing with few things in the community, especially doing multiple small services (such as providing ready-made dustbins for the city to tie to the central posts of the city, with a warning on each courtesy).

- Productive: When it stimulates the generation of skills (through technical courses and training in technical professions) or attempts to introduce the manufacture or cultivation of any other product than the one it produces.

- Sustainable Development: concern that the benefits it transfers remain after the mine has been depleted and closed.

The municipal government invests little in improvements for the local community, and its infrastructure. For example, the study about basic sanitation of the Center for Mineral Technology CETEM, by Fernandes et al. (2007). And usually the mineral enterprise acts in a welfare manner, according to Pasco-Font et al. (2003) has already talked about resolving a few problems in the community. Such as the various small services, for example. Most of the company's employees who have high salaries, when compared to the region, are brought from other locations because they are considered to have high professional qualifications. So, regional workers could earn more than the minimum wage.

From the results generated in this research and the socioeconomic information of the region, it can be seen that with the installation of the mining company, the population and the urban area increased. Consequently, the number of jobs coming from the enterprise increased, employing a large part of the city's inhabitants, thus reducing the rural population. However, the salary of these workers is low. A fact proven by comparing the income per capita with the history of the minimum wage in the period analyzed in the survey. This goes against the common consensus that brings a large international mining company will also bring high salaries. Thus, temporal evolution shows the mining expansion in the region, which changes the landscape in favor of economic development. However, such development is not effectively passed on to those who live with the environmental liabilities generated by the mineral activity. This activity changes the cultural aspects of the local population by being inserted as the economic base of the region.

\section{CONCLUSIONS}

The state of Goiás has a diverse geological environment, thus, several mineral deposits of different substances are found. Such concentration is mainly located in the North and South mesoregions. Leading to the installation of large industries of the mineral sector in the Goiano territory, resulting in changes in the natural landscape and their characteristics of origin that, in large part, are not minimized.
The evaluation of the Kappa index was satisfactory, obtaining a value considered high in the accuracy and quality in the classification of images. Overall, supervised image classification was also satisfactory, as field visit and Google Earth verification made it possible to differentiate usage and coverage classes. The mappings of the images in the mining area and its surroundings demonstrated the evolution of the landscape alteration, being observed from 2005, the year in which the operations of the enterprise began to intensify. It is also noteworthy that the significant increase in activities at the mine in 2015 , is $19.2 \%$ over the previous period analyzed.

The lack of availability of socioeconomic data from the municipalities prior to 1991 and after 2013 prevented relating old information to the most recent (1985-2015). Thus, it was not possible to obtain a historical evaluation of Alto Horizonte for over thirty years. However, from the available data, it can be inferred that, with the arrival of large mining in this municipality, there was an evolution in most of the socioeconomic indicators, mainly related to jobs. It was realized that the idea of having a large mining company installed in the region does not mean that there will be improvements in the salary of most employees who work there. Thus, issues such as health, wages, education, and urban infrastructure have not followed as successfully as economic indicators. CFEM is intended for the municipality to be applied in projects that, directly or indirectly, revert to the local community, in the form of improving infrastructure, environmental quality, health, and education. This leads to the conclusion that the transfer made by the enterprise was not invested properly, when talking about the welfare local population, either by deviations by the rulers or unplanned distribution of CFEM.

\section{ACKNOWLEDGMENTS}

The authors would like to thank the Federal District Research Support Foundation (FAPDF) and the Higher Education Personnel Improvement Coordination (CAPES) for their financial support.

\section{REFERENCES}

Atlas Brasil, 2013. Desenvolvimento Humano. www.atlasbrasil.org.br/2013/. (5 March 2019).

ADHOC, 2014. Clipping Semanal de Mineração. www.adhocadvisors.com.br/site/index.php?option=com_docma n\&task=cat_view\&gid=35\&Itemid=75. (2 July 2019).

Barreto, M. L. 2001. Mineração e desenvolvimento sustentável: Desafios para o Brasil. CETEM/MCT. Rio de Janeiro. 150 p.

Britto, M. C., Ferreira, C. C. M. 2011. Paisagem e as diferentes abordagens geográficas. In: Revista de Geografia - PPGEO - v. 2 , no 1, p.1-10

Cardoso Júnior, H. M., Lunas, D. A. L. 2016. Universo da Mineração em Goiás: Potencial Mineral e Principais Polos de Extração. Conjuntura Econômica Goiana, Dezembro, $n^{\circ}$ 39, 20 p.

Cavalcanti, A. P. B. 2004. Análise integrada das unidades paisagísticas na planície deltaica do rio ParnaíbaPiauí/Maranhão. In: Mercator - Revista de Geografia da UFC, ano 03 , n 06. 
Coelho, V. H. R., Montenegro, S. M. G. L., Almeida, C. N., Lima, R.V., Ribeiro Neto, A., Moura, G. S. S. 2014. Dinâmica do uso e ocupação do solo em uma bacia hidrográfica do semiárido brasileiro. Revista Brasileira de Engenharia Agrícola e Ambiental, v.18, n.1, p.64-72.

Corrêa, R. L. C., Castro, I. E., Gomes, P. C.C. 2008. Geografia: conceitos e temas. Rio de Janeiro: Bertrand Brasil.

DNPM, 2010. Departamento Nacional de Produção Mineral. Anuário mineral brasileiro 2010. www.dnpm.gov.br/assets/galeriaDocumento/AMB2010/GO_20 10.pdf. (2 May 2019).

DNPM, 2013. Departamento Nacional da Produção Mineral. Superintendência Goiás/Distrito Federal. Desempenho do Setor Mineral de Goiás - 2013 (ano base 2012). www.dnpm.gov.br/go/conteudo.asp?IDSeca. (15 June 2019).

Ellovitch, M. F. 2010. Ecodebate - Cidadania e Meio Ambiente. Conceito de sustentabilidade. www.ecodebate.com.br/2010/11/12/conceito-desustentabilidade-artigo-de-mauro-da-fonseca-ellovitch/. (5 June 2019).

Fernandes, F. R. C., Lima, M. H. R., Teixeira, N. S. 2007. Grandes minas e comunidade: algumas questões conceituais. Rio de Janeiro: CETEM/MCT: it. 58p. (Série Estudos e Documentos, 73).

Galparsoro, L. U., Fernández, S. P. 2001. Medidas de concordancia: el índice Kappa.

http://www.fisterra.com/mbe/investiga/kappa/kappa.htm. July 2019).

IBGE, 2015. Instituto Mauro Borges de Estatísticas e Estudos Socioeconômicos.

www.imb.go.gov.br/pub/pib/pibmun2013/pibmun2013.pdf. (15 February 2019).

IBGE, 2016. Instituto Mauro Borges de Estatísticas e Estudos Socioeconômicos CIDADES@. www.cidades.ibge.gov.br/xtras/home.php. (28 January 2019).

IBRAM, 2015. Instituto Brasileiro de Mineração. www.ibram.org.br/150/15001005.asp?ttCD_CHAVE=30374. (19 June 2019).

IBRAM, 2014. Instituto Brasileiro de Mineração. Empresas de olho no novo ciclo do ouro. www.ibram.org.br/150/15001002.asp?ttCD_CHAVE=228221. (22 November 2019).

Jensen, J. R. 2005. Introductory digital image processing: a remote sensing Perspective. 3rd Ed., Upper Saddle River: Prentice-Hall, p.544.

Mirim, V. 2019. Mineração e Desenvolvimento Sustentável. Clipping ADIMB - Agência para o Desenvolvimento Tecnológico da Indústria Mineral Brasileira. adimb.org.br/ADMBLACK/clipping/467.pdf. (9 November 2019).

MMIC, 2013. PGA - Programa de Gestão Ambiental. Lavra do Corpo Sul - Mineração Maracá Indústria e Comércio. Alto Horizonte, Goiás, 90 p.
Novo, E. M. L. 1992. Sensoriamento remoto: princípios e aplicações. 2. ed. São Paulo: Edgard Blücher, 308 p.

Pasco-Font, A., Hurtado, A. D., Damonte, G., Fort, R.; Salas, G. G. 2003. Capitulo 4 - Aprendiendo mientras se trabaja, In: McMahon, Gary; Remy, Félix (eds.). Grandes Minas y la Comunidad: efectos socioeconómicos en Latinoamérica. Canadá y España, Banco Mundial/Alfaomega, Ottawa.

Santos, R. F. 2004. Planejamento ambiental: Teoria e Prática. São Paulo: Oficina de Textos, 184 p.

Sano, E. E., Rosa, R., Brito, J. L., Ferreira JR, L. G. 2007. Mapeamento de cobertura vegetal do bioma Cerrado: estratégias e resultados. Planaltina: Embrapa Cerrados, 33 p. ISSN 15175111; 190. (Boletim de Pesquisa). bbeletronica.cpac.embrapa.br/2007/doc/doc_190.pdf. (5 June 2019).

Sano, E. E., Rosa, R., Brito, J. L., Ferreira, L. G. 2010. Land cover mapping of the tropical savanna region in Brazil. Environ Monit Assess, n. 166, p 113-124. DOI: 10.1007/s10661-0090988-4

Yaylaci, E. D., Düzgün, H. S. 2016. Indicator-Based StrategicLevel Sustainability Evaluation For Coal Mining Plan Alternatives. Conference: 22nd International Sustainable Development Research Society Conference, School of Science and Technology, Universidade Nova de Lisboa, At Lisbon, Portugal, Volume: Volume 1 of 3. 